\title{
INFLUENCE OF UNIVERSITY CURRICULUM DESIGN ON EMPLOYABILITY OF KENYAN GRADUATES: PUBLIC UNIVERSITIES PERSPECTIVE
}

\author{
Lilian Mwebia $^{1 *}$, Kavitah C. Kyuli ${ }^{2}$ \\ *1PhD Student, Jomo Kenyatta University of Science and Technology, P.O Box 62000-00100 Nairobi, Kenya Email \\ lilianmwebia@yahoo.com, Mobile 0724-821-192 \\ ${ }^{2}$ PhD Student, Jomo Kenyatta University of Science and Technology, P.O Box 62000- 00100 Nairobi, Kenya Email \\ carltonkavitah@yahoo.com, Mobile: +254 722501259
}

*Corresponding Author: -

Email: lilianmwebia@yahoo.com

\begin{abstract}
: -
Despite the rising levels of education in Kenya, many graduates face very high unemployment rates. This raises questions on the demand and market orientation of the university curriculum design and whether the university course designers are cognizant of labor market trends. It for this reason this paper sought to investigate the influence of university curriculum design on employability of Kenyan graduates. A descriptive survey research design was applied in this study. The paper gathered feedback on the influence of university curriculum design on employability of Kenyan graduates from graduates and employers of Super Markets in Nakuru Town. Data was collected from one hundred and forty (130) graduates and (10 managers) employers of graduates about the proficiency of graduates in relation to each of the employability capabilities as a result of graduating from undergraduate programs. Both qualitative and quantitative data from the surveys was analyzed. A descriptive statistical analysis approach was used to analyze the quantitative data. The study found that experience as a highly required factor in the job market. The study also found that internships as very useful especially for graduates looking for their first opportunity in the world of work. The study also found that industrial attachment for lecturers was important as it was thought to help them gain the industry practices. The study concluded that the experiential learning approach should be deliberately designed around an open-ended authentic project and negotiated between university and industry stakeholders. This study recommends creation of employer voice on skills through establishment of a commission for employment and skills. The study also recommends increasing university investment in internship in degree and postgraduate programs and strong partnership with employers while designing curriculum.
\end{abstract}

Keywords: Curriculum Design; Employability; Internship; Graduate Attributes; Higher Education; University Investment; Unemployment Rates

\section{(a) $(\$)$}




\section{INTRODUCTION}

Despite the rapid expansion of higher education enrolments, there are serious concerns about the ability of Kenya's universities to produce the kinds of graduates who are employable. Hence, employability of graduates is deemed an outcome universities should strive for as government, industry and students demand increased accountability measures. Most higher education institutions are exploring mechanisms for enhancing the student experience through the inclusion of authentic learning experiences and 'real world' assessment strategies in the curriculum. While 'getting a job' is a straight forward concept, the notion of employability and what it means to be employable is open to debate. In essence, the emphasis is on developing critical, reflective abilities, with a view to empowering and enhancing the learner (Harvey 2003).

Pegg et al.(2012) defined employability as "a set of achievements skills, understandings and personal attributes that makes graduates more likely to gain employment and be successful in their chosen occupations, which benefits themselves, the workforce, the community and the economy. In the twenty-first century workforce is expected to be prepared for a global experience that is fraught with complex workplace relationships and demands. According to Welikala (2011) the 21 st century University" has a "social responsibility to equip the members of the society with necessary competencies, knowledge, understandings, and new skills so that they can constantly negotiate the changing nature of work, the labour force, information technologies and cultural identities of people". Among these desirable skills, competencies and attributes include critical thinking, communication, and social responsibility.

Graduate attributes are emphasized in higher education as incentives to attract both learners and employers. Learners are encouraged to enroll into programs that emphasize global experience and work-ready skills and competencies making them sought after 'commodities' in a rapidly technologies world. Employers are persuaded that graduates hired from higher education institutions that are committed to embedding graduate attributes within the curriculum will enhance their corporate profiles. Generic attributes are emerging in importance in higher education, influenced by several factors including the popular view of education being lifelong process; increased focus on the influence of education on graduate employment; and the quality movement towards the development of outcome measures (Bath, Smith, Stein, \& Swann, 2004). A survey conducted by Gibney (2013) shows that students value high-quality, industry linked curriculum which is emphasized as a key measure of student experience. Therefore universities should enrich the learning journey through the promotion of employability and good industry connections providing opportunities for individual growth and maturity. Increasing the value of degrees and the doors they can open will help to invigorate the student journey, by providing a clear line of sight towards the professional market. The process should develop closer relations with employers, providing greater breadth and depth to the student experience. The core set of skills the research intends to focus on were founded commercially, which promotes greater student focus beyond skills to considering the values and attitudes required by professionals. This builds students' confidence in their eligibility for responsible roles.

While graduate attributes are growing in prominence, the attribute of industry linked curriculum has been given less attention in higher education. In fact, the education sector has been increasingly criticized for its failure in effectively link their curriculum development to industry, which is critical for graduate employability and international competitiveness (Kim, 2011; Kimbell, 2009; Kirby, 2004). Clarke (2013) argues that universities focus excessively on storytelling approaches about entrepreneurs, business planning competitions or lean start up models excluding other models for developing creativity skills. He calls for more rigorous approaches to curriculum development and teaching creativity.

In extending the notion that the employability of graduates is intricately related to the higher education quality and attributes that graduates receive, it is necessary to note that employability is approached in different ways. For instance some studies in the UK indicated that employers are considering more about varieties of skills than the speciality (Gunawardena 1997). According to a study conducted in UK among 52 business institutions, 90\% of them pointed out that most important quality of a graduate are communication skills. Except that, Quality of Higher Education study in UK also identified some other important characteristics such as subject knowledge, research and analytical ability, inter personal relations, problem solving, self confidence, self management, decision making and judgment skills among others. The other virtues and skills that are expected from graduates are, genuineness, humbleness, obedience, credibility, tactfulness, sensitiveness, cooperation, devotion, active, straightness, unchangeable, altruistic, new thinking, leadership, strength, organizational skills, time management, skills of discussion, commercial knowledge and personality (Gunawardena, 1997). Quite often in Kenya, industry players have criticized universities by asserting that university curriculum is normally not designed in tandem with societal changes. For this reason, stakeholders often chide concerning the skill mismatch between the academic programmes offered at the universities and the requirements of the labour market. It is not uncommon nowadays for the employers to complain that the grade one scores at the university does not correlate positively to performance at work. The purpose of this paper therefore is to discuss the process underlying curriculum design and implementation and its effect on employability of students learning outcomes at the university level in Kenya. Very few graduate recruiters reported that they frequently cooperated with universities on curriculum design and study programmes, and more than half reported that they had never done so. It for this reason this paper sought to investigate the influence of university curriculum design on employability of Kenyan graduates 


\section{Statement of the Problem}

The major objective of promoting children for higher education in most of Kenya families is to ensure their employability (Perera, 2008). Accordingly, almost all Kenyan families are having greater aspiration of providing university education for their children as a secured path of higher employability. This is because graduates are considered as one of the most important human capital expected to work in a middle or top management level in providing services to society in various ways. Therefore, in Kenya, there is a considerable demand for higher education. However, many students, who enter the universities, have to face numerous challenges especially at the end of the graduation in seeking suitable employments.

Experience reveals that even talented graduates have to wait for a long time to be employed after the graduation. Many of the graduates having passed out obtain a certificate, which does not help enough them to find suitable employments. Even if one of the main objectives of the university education is to improve the skills of students to face the challenges in external society, they have to leave from the university without having sufficient self-confidence and assurance for better employments. Under this circumstance, graduates' unemployment has become a severe problem in Kenya during the last few decades.

In many situations, the reality is that the qualification along does not help enough to find a job because of the mismatch between the demand and the supply of the job market. Therefore, some graduates have to be engaged in irrelevant jobs mostly under low salaries while some of them have to be unemployed and waiting for a long time mostly until the government provides opportunities. Such graduates will become a burden not only for their families but also to the whole country. The effects of this would be arisen as frustration, youth unrest, violence, and other forms of anti-social behaviours. Within this context, it is important to identify why graduates cannot find suitable jobs as soon as they pass out from universities. And why is the country's employment sector not capable to absorb such graduates into the development process? Therefore, the main objective of this paper is to discuss the influence of university curriculum design on employability of Kenyan graduates.

\section{Literature Review}

Universities in Kenya have the freedom to develop their programs and adapt them to the market needs (commission for university education, 2013). This kind of education system tends to borrow from the American education system which is much renowned for its flexibility and academic freedom (Mautusi, 2013). One of the characteristic features of the university education in Kenya is that it has no common curriculum for a specific discipline that is followed by undergraduate and graduate programmes in universities as each university has the freedom to develop its own curricular (commission for university education, 2013). This academic flexibility and freedom are more often followed by universities that have adopted the American system of education.

This view is corroborated by Mautusi (2013) who has observed that universities in Georgia, which largely follow the American system, depict a tendency where there is variation in course content presented in class by two lecturers teaching at two institutions or sometimes teaching the same course in same department. This situation is not different from the Kenyan case which is touted as the prototype of the American system with its problems mirroring those faced by the Georgian Universities (Mautusi, 2013). In Kenya, there is no central body judged with the responsibility of curriculum development at the university level. Each university designs its curriculum based on its peculiarities and uniqueness.

Irrespective of this, however, curriculum design is guided by the commission for university education which is responsible for maintaining quality standards in higher education. According to CUE guidelines, university curriculum is often designed by the individual departments with the more experienced lecturers giving their input regarding the content to be included in the curriculum. The content is often internally peer reviewed at the department and school/faculty before it is presented to the senate for adoption. After the senate has adopted the programme, it is then presented to the commission for university education (CUE) for external review (commission for university education, 2013). Once it has been accepted by the commission for university education, the university can go ahead and implement the curriculum after incorporating the recommendations suggested by the CUE (commission for university education, 2013).

Kuratko (2005) argues that although universities have evolved beyond the myth that creativity is a birth trait and cannot be taught, universities should address the relevant question concerning how creativity skills should be developed. He suggests that experiential learning can be an effective approach in developing creativity skills. In Australia, the term Work-Integrated Learning is used to describe experiential learning strategies for combining classroom studies with learning through work experiences that are related to academic goals (Groenewald, 2004). The shift from an industrial society to information and knowledge society has far-reaching implications for the kinds of skills needed by the workforce and the population at large (Voogt and Pareja Roblin, 2010 and Allen and Van der Velden, 2012). Voogt and Pareja Roblin (2010) assert that although the changes are taking place in widely differing sectors of the economy, there is a common set of core ' 21 st century skills' that are needed in virtually all domains.

The European Commission (2007) defines eight key competences that the employer of today may demand from fresh graduates from university; communication in the mother tongue, communication in foreign languages, mathematical competence and basic competences in science and technology, digital competence, learning to learn, social and civic 
competences, sense of initiative and entrepreneurship, and cultural awareness and expression. These are the skills that according to many are needed in order to function adequately in, and make a useful contribution to the knowledge and information society in the 21 st century.

As Allen and Van der Velden (2012) have pointed out, these 21st century skills do not exist in a vacuum, but form part of a complete interdependent package comprising basic and specific skills as well as 21 st century skills. The Euro barometer survey on 'Employers' perception of graduate employability' (2010) showed that most important skills needed by employers are team working skills, followed by sector-specific skills, communication skills, computer skills, being able to adapt to new situations, ability in reading/writing and analytical and problem-solving skills. In addition to skills, most employers stressed the importance of work experience of graduates, and a high proportion named sectorspecific work placements as a key path for universities to improve the employability of their graduates. From the foregoing literature, it can be argued that the curriculum development process at the university level in Kenya is facing a myriad of challenges in this century. With the continuous exponential growth of university education, there ought to be a paradigm shift in light of curriculum design and development so that graduate employability is not compromised.

\section{Methodology}

In order to address the issue of employability of graduates of Kenyan Universities, a questionnaire was developed based on views of level of competencies of graduates by the degree program and the employers' requirements from a graduate. Two methods were applied to collect data relating to employers' requirements from a graduate. Interviews regarding data on level of competencies of graduates were conducted with 10 managers working with leading supermarkets in Nakuru town. In addition a questionnaire was distributed among a random sample of 130 graduates and 10 managers working with leading supermarkets in Nakuru town regarding employment opportunities for graduates. Different views were descriptively analyzed with a view to comprehend the magnitude of the issue.

\section{Discussion Of Results}

The paper also recognizes the challenges facing university education in Kenya in the wake of university expansion and transformation in the 21 st century from the curricular perspective by examining the imperatives of assessing university graduate employability. The paper is informed by the fact that employers have decried the quality of graduates from public universities in Kenya as observed by Amimo in Ponge (2013). This has often been blamed on the mismatch between the academic skills and the labour market (Riechi, 2008; Ponge, 2013). The paper however argues to the contrary pointing out that the problems threatening the employability of university graduates could be attributed to the manner of curriculum design than skill mismatch. The findings are illustrated below:

\section{Employers' Requirements from a Graduate}

This survey sought to establish the skills and competences the employers need for current jobs. The results are shown in table1.

Table1: Requirements in the Current Market

\begin{tabular}{|l|l|}
\hline Needed Requirements & $\%$ \\
\hline Computer skills & 42 \\
\hline Communication skills & 63 \\
\hline Training/ work experience & 73 \\
\hline Teadership/ decision making & 21 \\
\hline Peamwork /interpersonal skills & 45 \\
\hline Problem solving/analytical skill & 21 \\
\hline
\end{tabular}

Source: Survey data 2013/2014

Findings in table 1 show that training/experience $(73 \%)$ is the highly required factor in the job market. However, without having considerable links with the study programs and stakeholders it is not easy to have experience or training for graduates. This means internships or post attachment is very useful especially for graduates looking for their first opportunity in the world of work. Therefore students after graduation should seek for internship so that they can get linked with local employers whom they can demonstrate their knowledge and skills. But this should be emphasized during curriculum designing for good follow up.

On the other hand proficiency of English $(63 \%)$ and IT skills $(42 \%)$ are also considerable requirements in the job market. Therefore, students seeking for job opportunities are compelled to develop English proficiency which be challenge because university curriculum design does not much on developing the skill. It important to note that, students who are less proficiency in English are hardly employable. Further, team work/interpersonal relations (45\%), is also considerable factor in the job market. Except these, leadership qualities, and especially problem solving and analytical ability, are the other highly demanded requirements of the current job market. Therefore, graduates must have additional skills such as leadership qualities, team work/interpersonal relations and especially problem solving and 
analytical ability, which are highly needed in the job market.

In support of the above findings, some studies in the UK show that employers are considering more about varieties of skills than the speciality. For instance, British industrial and commercial fields need graduates who possess various skills and adoptability (Gunawardena 1997). According to a study conducted among 52 business institutions, 90\% of them pointed out that most important quality of a graduate are communication skill. Except that, Quality of Higher Education study has identified some other important characteristics such as subject knowledge, research and analytical ability, inter personal relations, problem solving, self confidence, self management, decision making and judgement skills etc.

The other virtues and skills that are expected from graduates are, genuineness, humbleness, obedience, credibility, tactfulness, sensitiveness, cooperation, devotion, active, straightness, unchangeable, altruistic, new thinking, leadership, strength, organizational skills, time management, skills of discussion, commercial knowledge and personality etc (Gunawardena, 1997). Additionally, English proficiency, and IT skills, etc. have been critical determinants of graduates' employability in many organizations (Perera, 2005). On what factors are considered by employers when selecting a graduate, result of the British study show that the highest rate $(34 \%)$ of the respondents had pointed that communication skills was mostly expected skill in selecting graduates for employment.

The other highlighted qualities are external appearance, manners, ethics, personality, respect to others, team work ability, interpersonal skills, leadership etc. In addition, $66.7 \%$ of government sector employers and $89.6 \%$ of private sector employers have emphasized the importance of proficiency of English language (Gunawardana, 1991). Hettige (2000) explains some attributes such as the ability to lead a team and ability to achieve results in a short period, ability to prioritise/ organize time productively, openness, positive thinking, practical mind set, willing to learn from a cross section of people, general knowledge including world affairs, wide interest, personal grooming and business etiquette are also determinants of graduates employability.

It can be argued that these characteristics cannot be developed by conventional teaching learning and evaluation methods but should be part and parcel of the curriculum design.

\section{Curriculum Design and Employability}

Even though the problem of graduates' unemployment is partially a result of economic development, the society tends to perceive it as a result of quality of the operations of the university system. Accordingly, the main problem for the graduates' unemployment relates with the preparation of the students for job market. Therefore, the Kenyan universities should seriously evaluate the relevancy and quality of curriculum design they delivery to their students and whether it can attract them to available market jobs. Some findings based on curriculum design offered in universities in Kenyan are provided in table 2 below.

Table 2 Curriculum Design and Employability

\begin{tabular}{|c|c|c|c|c|c|}
\hline Statement & $\begin{array}{l}\text { Strongly } \\
\text { Agree }\end{array}$ & Agree & $\begin{array}{l}\text { Don't } \\
\text { Know }\end{array}$ & Disagree & $\begin{array}{l}\text { Strongly } \\
\text { Disagree }\end{array}$ \\
\hline $\begin{array}{l}\text { Curricula design taught influenced my } \\
\text { employability }\end{array}$ & 27.7 & 49.1 & 0 & 17.5 & 5.7 \\
\hline $\begin{array}{l}\text { Teaching Methods used during my } \\
\text { studies influenced my employability }\end{array}$ & 38.0 & 9.4 & 0 & 22.6 & 20.0 \\
\hline $\begin{array}{l}\text { Curriculum Change is needed to improve } \\
\text { students }\end{array}$ & 3.8 & 7.5 & 18.9 & 50.9 & 18.9 \\
\hline employability & 5.7 & 13.2 & 26.4 & 32.1 & 22.6 \\
\hline $\begin{array}{l}\text { Departments should Guide Curriculum } \\
\text { Designers }\end{array}$ & 7.5 & 9.4 & 24.5 & 32.1 & 26.4 \\
\hline $\begin{array}{l}\text { Involvement of employers in university } \\
\text { curriculum designing is needed }\end{array}$ & 38 & 21.3 & 16.7 & 15.8 & 8.2 \\
\hline $\begin{array}{l}\text { Use of internships and work based } \\
\text { learning influenced my employability }\end{array}$ & 56.6 & 30.2 & 3.8 & 5.7 & 3.8 \\
\hline $\begin{array}{l}\text { Curricula designers indeed integrate } \\
\text { industry practices }\end{array}$ & 86.8 & 0 & 11.3 & 1.9 & 0 \\
\hline $\begin{array}{l}\text { Workshops should be introduced as } \\
\text { method of teaching in universities. } \\
\text { Curricula designers need to introduce } \\
\text { industrial attachment for lecturers }\end{array}$ & 13.0 & 17.4 & 8.7 & 52.2 & 8.7 \\
\hline
\end{tabular}

Source: Survey data 2013/2014

On whether Curricula design taught in university influenced employability, $76.8 \%$ of the respondents agreed with the statement, while $23.2 \%$ disagreed with the statement. Therefore it our believe that employability is a responsibility that should be shared equally between individuals (universities) who must be responsible for accepting the consequences of 
their choices and business owners who employ university graduates to serve their customers so as to inculcate particular values and attitudes as well as shaping behaviours of the graduate. This can be true if universities can develop curriculum in conjunction with other stakeholders. On whether teaching methods used in teaching the curriculum influenced employability, $47.4 \%$ of the respondents agreed with the statement while $42.6 \%$ disagreed with the statement. This indicated that methods applied in teaching different concepts to the graduate determined their confidence in various skills needed for employability. Therefore the teaching methods should be geared towards developments of most soft skills.

The findings also show that majority $(69.8 \%)$ of the respondents disagreed that being involved in curriculum change influenced their employability while $18.9 \%$ were not aware or sure and only $11.3 \%$ disagreed with the statement. It is important to note that involvement of the students in curriculum was not as important as involvement of the employers in designing of university curriculum. Hence mechanisms must be put in place to monitor labor market signals before making any changes in curriculum to avoid wastage of human resource and also the resources used to train these graduates in various fields.

The findings of the study further show that majority $(54.7 \%)$ of the respondents were of the opinion that university departments should not completely guide Curriculum designers in curriculum development. But should keeps curriculum designers informed on trends in the labour market. Likewise, most respondents rated involvement of employers in university curriculum designing as undesirable at $58.5 .8 \%$ while $16.9 \%$ of them saw the involvement of employers in course and curriculum design as desirable or appropriate. However, there appears to be no fundamental reason why universities and employers cannot reach a consensus on educational approaches that promote employability. Further majority $(59.3 \%)$ of the respondents indicated that use of internships and work based learning could influence graduates employability. However, a minority (24\%) of the respondents did not see use of internships and work based learning to influence graduates employability. Indeed, it is arguable that integration of classroom teaching with internships and work based learning could influence graduates employability as both will wider abilities, capacities and advancement of the graduate expected to join employment. Traditional methods teaching typically used in universities are not adequately designed for capturing students' ability to apply generic skills in a practice-based setting. The inclusion of authentic learning experiences which provide opportunities for students to practice work-based skills are resource intensive and require specific expertise and professional development. According to Layer (2006) strategies around teaching and learning and student support need to change in order to have an impact on the acquisition of employability capabilities.

Most respondents (86.6\%) agreed that curricula designers should integrate industry practices into curriculum development process so as to increases graduates employability. Refocusing education providers to addressing industry outcomes will require a major cultural shift for institutions and initiate significant professional change and adaptation for many staff (Australia, 2011).

Almost all respondents $(86.8 \%)$ agreed that workshops should be introduced as method of teaching in universities so as to increase graduates employability as it will expose them to what is happening in the industry. The study notes that workshops will make the students to develop attributes, characteristics and skills for graduate employability such as strong communicators - both written and oral, be able to work using their own initiative, capable of doing independent work, be creative and able to solve problems, time management and presentation skills as well as be able to work as part of a team and network with others among other skills.

Majority (30.4\%) of the respondents agreed that Curricula designers need to introduce industrial attachment for lecturers so that they can gain the industry practice. The finding supports the notion that teaching staff in universities do not have all exact capabilities to articulate what the industry need.

The evident gaps in the curriculum also has implications for resourcing teaching areas to incorporate authentic experiences and engage with industry thereby establishing partnerships to enrich the student experience.

\section{Conclusions and Recommendations}

Even though graduates are highly valuable human resource of a country, most of them have to wait for a long time for suitable jobs due to mismatch between the degree and the demands of the job market. Issues in the development of curriculum for universities in this country appear as a greater drawback in case of graduates' employability. This because the findings support the calls for an increased focus on "soft skills" such as communication, leadership, collaboration and innovation in education which are rarely considered (Raelin, 2006; Sternberg, 2003). These should be highly considered since they are critical to students' success in industry projects.

It is worth noting that the experiential learning approach investigated in this study should be deliberately designed around an open-ended authentic project and negotiated between university and industry stakeholders, in the context of which innovation was a priority. This design could be instrumental in allowing scope for the complexity of planning and thinking that is required for the development of both leadership capacities and the skills associated with creativity. This is because employers are placing increased demands on university graduates for creativity in leadership. The traditional notion of leadership without an emphasis on creative attributes is no longer adequate in a highly competitive 
global job market. It should be noted that in the current global economy, leaders must learn to find creative solutions instinctively and spontaneously to generously advance the profit-margins of industry in order to keep their place in the organization. Hence universities must step up to the challenge of inspiring tomorrow's leaders to demonstrate creativity in leadership through an authentic curriculum design for employability.

\section{Recommendations}

Among the outcomes of the above reviews should be a clearer understanding of how the programme assists the students in meeting employers' expectations; quality of instruction, research, and public service; value to students' general education and preparation for society; resource requirements; future objectives and changes necessary to achieve them. Labour market players should be widely incorporated in the review of academic courses. Regular surveys need to be undertaken to obtain perceptions of university students on various jobs and industry. Such studies shall produce information that would inform curriculum development process in Kenyan universities so as to make higher education in Kenya more relevant to the country's current and future development needs. University programmes offered in the country should be monitored to ensure that they Instill skills for self employment, self reliance and self direction on the part of the learners. This would compel the learning institutions to offer programmes that are more relevant and reduce the menace of unemployment.

The government should embark on measures meant for strengthening the employer voice on dictating the types of skills that should be created by universities as well as the contents of academic programmes offered. Universities in Kenya should value and provide an enabling environment for encouraging partnerships and consultations with employers. This will assist in development of university programmes that are relevant to the job market and improvement in the courses design.

With growing calls for university programs to become more relevant to the workplace, there is a clear need for further research into understanding and assessing the outcomes of different forms of experiential learning in relation to the stated objectives and presumed benefits of these program components. In particular, the role of industry-based experiences in developing students' capacities for creativity in leadership is worthy of attention from researchers.

\section{Reference}

[1] Abeysekera, I. (2006). Issues relating to designing a work-integrated learning program in an under-graduate accounting degree program and its implications for the curriculum. Asia- Pacific Journal of Cooperative Education, 7(1), 7-15.

[2] Ariyawansa R. G. and Perera M. A. N. R. M. (2005), Determinants of Graduates Employability, Paper presented at the 10th International Conference of Sri Lankan Studies, University of Kelaniya, Sri Lanka

[3] Austalian Learning and Teaching Council. (2011). Assuring graduate attributes

[4] Bath, D., Smith, C., Stein, S., \& Swann, R. (2004). Beyond mapping and embedding graduate attributes: bringing together quality assurance and action learning to create a validated and living curriculum. Higher Education Research \& Development, 23(3), 313-328.

[5] Bottomley A and Williams, H (2006). Employability: Higher Education Institutions Engaging with Employers.

[6] Carson, D., Gilmore, A., Gronhaug, K., \& Perry, C. (2001). Qualitative research in marketing. London, U.K.: Sage.

[7] CHEC (2013). Pathways from University to Work. Wynberg: Cape Higher Education Consortium.

[8] Choudhrie, J., Papazafeiropoulou, A., \& Lee, H. (2003). A web of stakeholders and strategies: A case of broadband diffusion in South Korea. Journal of Information Technology, 18(4), 281-290.

[9] Clark, P. (2013, August 8). Entrepreneurship education is hot: Too many get it wrong.

[10] Bloomberg Business week.

[11] Commission for University Education. (2013). Draft Guidelines for University Courses. Nairobi: Commission for University Education.

[12] Creswell, J. (2009). Research design: Qualitative, quantitative and mixed method approaches.

[13] Los Angeles, CA: Sage.

[14] D'abate, C. P., Youndt, M. A., \& Wenzel, K. E. (2009). Making the most of an internship: An empirical study of internship satisfaction. Academy of Management Learning \& Education, 8(4), 527-539.

[15] Day, D. V., Gronn, P., \& Eduardo, S. (2006). Leadership in team-based organizations: On the threshold of a new era. The Leadership Quarterly, 17, 221-216.

[16] Friedrich, T. L., Vessey, W. B., Schuelke, M. J., Ruark, G. A. and Mumford, M. D. (2009). A framework for understanding collective leadership: The selective utilization of leader and team expertise within networks. The Leadership Quarterly, 20, 933-958.

[17] Galloway, L., \& Brown, W. (2002). Entrepreneurship education at university: A driver in the creation of high growth firms. Education \& Training, 44(8/9), 398-405.

[18] Githua, B., Macharia, K., \& Mboroki, G. (2009). Methods of Instruction: A Guide for Teachers and Teacher Educators. Nairobi: Kijabe Printing Press.

[19] Groenewald, T. (2004). Towards a definition for cooperative education, in R. K. Coll \& C. Eames (Eds.), International handbook for cooperative education: An international perspective of the theory, research and practice of work-integrated learning. Boston, MA: World Association for Cooperative Education, 17-25.

[20] Gudo, C., Alel, M., \& Oanda. (2013, November). University Education in Kenya and Issues of Quality Education: 
Challenges and Prospects. International Journal of Business and Social Sciences, 2(203), 203-214.

[21] Handscombe, R. D., Rodrigues-Falcon, E., \& Patterson, E. A. (2008). Embedding enterprise in science and engineering departments. Education \& Training, 50(7), 615-625.

[22] Harrison, R., Cooper, S., \& Mason, C. (2004). Entrepreneurial activity and the dynamics of cluster development: The case of Ottawa. Urban Studies, 41(4/5), 1045-1070.

[23] Hegarty, C. (2006). It's not an exact science: Teaching entrepreneurship in Northern Ireland.

[24] Education \& Training, 8(5), 322-335.

[25] Hettige S. T. (2000), Students' Counselling and Welfare Service in the University System of Sri Lanka in Talent Development and Utilization, University of Kelaniya, Colombo.

[26] Layer, G. (2006). Widening participation and employability. Learning and Employability Series: Learning and Support Network

[27] Katula, R. A., \& Threnhauser, E. (1999). Experiential education in the undergraduate curriculum.

[28] Communication Education, 48, 238-255.

[29] Kayes, D. C. (2002). Experiential learning and its critics: Preserving the role of experience in management education. Academy of Management Learning and Education, 1(2), 137- 149.

[30] Kim, K. H. (2011). The creativity crisis: The decrease in creative thinking scores on the Torrance tests for creative thinking. Creativity Research Journal, 23(4), 285-295.

[31] Kimbell, R. (2009). Creativity in crisis. The Journal of Design and Technology Education, 5(3), $206-211$.

[32] Kirby, D. A. (2004). Entrepreneurship education: Can business schools meet the challenge?

[33] Education and Training, 46(8/9), 510-519.

[34] Kuratko, D. F. (2005). The emergence of entrepreneurship education: Development, trends and challenges. Entreneurship, Theory and Practice, 27(5), 577-597.

[35] Lucas, W. A., Cooper, S. Y., Ward, T., \& Cave, F. (2009). Industry placement, authentic experience and the development of venturing and technology self-efficacy. Technovation, 29, 738-752.

[36] Mautusi, M. (2013, November 4). West Georgia University. Retrieved from West Georgia University: Www.Evaluation.Com/Program

[37] McWilliam, E., \& Dawson, S. (2008). Teaching for creativity: Towards sustainable and replicable pedogogical practice. Higher Education Research \& Development, 56, 633- 643.

[38] Mustar, P. (2009). Technology management education: Innovation and entrepreneurship at MINES ParisTech, a leading French engineering school. Academy of Management Learning and Education, 8(3), 418-425.

[39] Mwebi, R. B. (2012). Teacher Education in Kenya. Germany: Lap Publishers. National Academy for Academic Leadership. Retrieved from www.thenationalacademy.org

[40] Omollo, J (2012). 'Youth Employment in Kenya: Analysis of Labour Market and Policy Interventions'. FES Kenya Occasional Paper, No. 1.

[41] Omolo, OJ (2010). The Dynamics and Trends of Employment in Kenya, IEA Research Paper Series, No. 1/2010, Nairobi: Institute of Economic Affairs.

[42] Orrell, J. (2004). Work-integrated learning programmes: Management and educational quality Proceedings of the Australian Universities Quality Forum 2004. [AUQA Occassional Publication]. Adelaide. Australia.

[43] Patel, F. (2012, September). Journey to the future and back: Critical reflections on academic development practice HERDSA News.

[44] Pegg, A., Waldorf, J., Hendy-Isaac, S., \& Lawton, R. (2012). Pedagogy for employability. UK: Higher Education Academy.

[45] Perera M. A. N. R. M. (2006), Education Problems in Sri Lanka, Paper presented at the National Conference on Economic Development, at Guru Nanak Dev University, Amritsar, India.

[46] Perera M. A. N. R. M. (2008), Impact of Socialization Agents on Students' Mental Health, Paper presented at Conference Conducted by the National Centre for Advanced Studies,

[47] University Grants Commission, Colombo.

[48] Ponge, A. (2013, Feb). Graduate Unemployment and Unemployability in Kenya: Transforming University Education to Cope With Market Demands and the Lessons for Africa. International Journal of Social Science Tomorrow, 2(3), 1-12.

[49] Raelin, J. (2006). Does action learning promote collaborative leadership? Academy of Management Learning and Education, 2006(5), 2.

[50] Republic Of Kenya. (2012). Task Force On Realignment Of Education To The New Constitution and Vision 2030. Nairobi: Government Printer.

[51] Rhodes, L. (2008). Reflecting on 50 years of education and training: Viewpoints from the editorial advisory board. Education \& Training, 50(1), 40-41.

[52] Riechi, A. O. (2008, Feb N.D). Demand for Academic Programmes Offered in Kenya's Public Universities and their Relevance to the Labour Market.

[53] Schendel, R (2013). A Critical Missing Element: Critical Thinking at Rwanda's Public Universities and the Implications for Higher Education Reform (PhD thesis). London: Institute of Education.

[54] Shanks, G., Rouse, A., \& Arnott, D. (1993). A review of approaches to research and scholarship in information systems. Paper presented at the Fourth Australian Conference in Information Systems, Brisbane, Qld, Australia.

[55] Smith, A. M., \& Fischbacher, M. (2005). New service development: A stakeholder perspective.

[56] European Journal of Marketing, 39(9/10), 1025-1048. 
[57] Solomon, G. T., Duffy, S., \& Tarabishy, A. (2002). The state of entrepreneurship education in the United States: A nationwide survey and analysis. International Journal of Entrepreneurship Education, 1(1), 65-86.

[58] Sowel, E. (2000). Curriculum:An Integrative Introduction. Upper Saddle River, Nj: Prentice- Hall.

[59] Sternberg, R. J. (2003). WICS: A model of leadership in organizations. Academy of Management Learning and Education, 2(4), 386-401.

[60] Trott, P. (2008). Innovation Management and New Product Development. Essex, U.K.: Pearson Education.

[61] UNESCO Institute for Statistics (UIS) (2009) Global Education Digest 2009: Comparing Education Statistics Across the World: Montreal: UIS.

[62] United Nations (2011) The World Population Prospects: The 2010 Revision: Volume I: Comprehensive Tables New York: United Nations Department of Economic and Social Affairs.

[63] Van der Berg, S and Van Broekhuizen, H (2012). 'Graduate Unemployment in South Africa: A much exaggerated problem'; Stellenbosch Economic Working Papers: Vol. 22, No. 212.

[64] Welikala, T. (2011). Rethinking international higher education curriculum: Mapping the research landscape. [Position paper] Retrieved, from http://www.ucd.ie/t4cms/Rethinking\%

[65] Wickramarachchi M. W. (2008), Employability of Management Graduates, Convocation Address, 35th Convocation of the University of Sri Jayewardenepura, University of Sri Jayewardenepura, Colombo.

[66] World Bank (2014) Youth employment in Sub-Saharan Africa: Africa Development Forum.

[67] Washington: World Bank.

[68] Yin, R. K. (1994). Case study research: Design and methods. Beverley Hills, CA: Sage. 